\title{
High-throughput SPE-LC-MS/MS method for determination of indapamide in human serum
}

\author{
Natalija Nakov ${ }^{1 *}$, Kristina Mladenovska ${ }^{1}$, Dimche Zafirov $^{2}$, Aleksandar Dimovski ${ }^{1}$, \\ Rumenka Petkovska ${ }^{1}$, Aneta Dimitrovska ${ }^{1}$, Zoran Kavrakovski ${ }^{1}$ \\ ${ }^{1}$ Faculty of Pharmacy, University of "Ss Cyril and Methodius", 1000 Skopje, Republic of Macedonia \\ ${ }^{2}$ Institute of Preclinical and Clinical Pharmacology and Toxicology, Medical Faculty, University of "Ss Cyril and \\ Methodius", 1000Skopje, Republic of Macedonia
}

Received: February 2013; Accepted: April 2013

\begin{abstract}
Simple, automated SPE procedure combined with fast LC-MS/MS chromatographic separation resulted in obtaining high-throughput LC-MS/MS method for determination of indapamide in serum. The SPE procedure was performed on polymeric mixed-mode sorbent and the analytes were quantitated using electrospray ionization in positive mode. The recovery of indapamide and internal standard were $89.25-$ $90.36 \%$ and $79.10 \%$, respectively. Experimentally it was confirmed that the matrix effect had a negligible effect of ionization efficiency. The validation data showed that the proposed method provides accurate and reproducible results in range of $0.50-50 \mathrm{ng} / \mathrm{mL}$. In addition, a comparison was made between the method for determination of indapamide in serum and in blood (develop in our previously work) regarding the extraction procedure and matrix effect.
\end{abstract}

Keywords: indapamide; human serum, solid-phase extraction, liquid chromatography-tandem mass spectrometry

\section{Introduction}

Indapamide is a sulphonamide derivative pharmacologically related to thiazide diuretics. Indapamide is preferentially and reversibly taken up by the red blood cells, but it is also highly bound to plasma proteins (Dollery, C. 1999). The concentration of indapamide, for the needs of pharmacokinetic studies, can be estimated from blood or plasma/serum. The possibility of lysis of the erythrocytes makes its determination from blood more appropriate and precise. There are number reports concerning determination of indapamide in whole blood using high-performance

\footnotetext{
* MSci Natalija Nakov

phone: +3892 3126032; fax: + 38923123054

email: natalijan@ff.ukim.edu.mk
}

liquid chromatography with ultraviolet detection (HPLCUV) and liquid chromatography coupled with mass spectrometry (LC-MS) (Miller et al., 1993; Zendelovska et al., 2003; Tang et al., 2005; Hang et al., 2006; Jain et al., 2006; Nakov et al., 2013).

However, the literature data have shown that indapamide plasma/serum concentrations can also be used for clinical applications. Several HPLC-UV methods for determination of indapamide in plasma have been published (Choi et al., 1982; Gaetani et al., 1986; Zendelovska et al., 2003). In the recent years the number of reported LC-MS methods for estimation of indapamide in human plasma/ serum increases, mainly due to the specificity and sensitivity of the MS detector. Albu et al. (2005) and Ding et al. (2006) described LC-MS method using liquid-liquid extraction (LLE) procedure for determination of indap- 
amide in serum under isocratic conditions, within $11 \mathrm{~min}$ and $5 \mathrm{~min}$, respectively. Another published LC-MS method (Chen et al., 2006) employs LLE and gradient elution with a runtime of $7.5 \mathrm{~min}$. LC-MS/MS method using automated 96-well SPE for determination of indapamide in human serum was described by Morihisa et al (2008). Even though the method showed excellent sensitivity, the separation was performed under gradient elution within $16 \mathrm{~min}$.

In our previously work, we have developed an automated SPE-LC-MS/MS method for determination of indapamide in human whole blood within 3 minutes (Nakov et al., 2013). The objective of this work was to develop an automated SPE procedure for determination of indapamide in serum taking the advantage of the fast chromatographic separation attained in the previous work. The proposed method was validated in order to establish that it will continue to provide accurate, precise and reproducible results during the real study sample analysis. In addition, comparison of the two methods (determination of indapamide in serum vs. blood) in terms of extraction procedure and matrix effect was done.

\section{Experimental}

\section{Chemicals and standards}

Indapamide (purity 97.6\%) and zolpidem tartarate reference standards were purchased from EDQM (Strasbourg, France). Methanol, acetonitrile, water (MS grade) and ammonium acetate and potassium hydrogen phosphate dibasic (analytical grade) were supplied from Sigma-Aldrich, Germany. Formic acid and potassium hydroxide pellets (analytical grade) were purchased from Merck, Germany.

\section{Instrumentation and experimental conditions}

The HPLC-MS/MS system consisted of Shimadzu LC-30 Nexera coupled to a Shimadzu LCMS 8030 triple quadrupole mass spectrometer with an electrospray ionization (ESI) interface. Data were acquired using Shimadzu LCMS LabSolution software. Automated SPE was performed on RapidTrace workstation (Biotage AB), controlled by RapidTrace V 2.0 software.

Chromatographic separation was achieved on Kinetex C18 column $(100 \times 2.1 \mathrm{~mm}, 1.7 \mu \mathrm{m}$ partical size $)$ using acetonitrile and $2 \mathrm{mM}$ ammonium acetate (added $0.5 \mathrm{~mL}$ formic acid in $1 \mathrm{~L}$ buffer) in ratio $90: 10(v / v)$ as a mobile phase. The flow rate was $0.2 \mathrm{~mL} / \mathrm{min}$ and the injection volume $10 \mu \mathrm{L}$. The column temperature was $30^{\circ} \mathrm{C}$ and the autosampler temperature was set at $15{ }^{\circ} \mathrm{C}$. The run time was 2.5 minutes. Mass spectrometric conditions were as follows: drying gas $11.0 \mathrm{~L} / \mathrm{min}$, nebulizing gas $2.4 \mathrm{~L} / \mathrm{min}$, desolvation line temperature $280^{\circ} \mathrm{C}$, heat block temperature $430{ }^{\circ} \mathrm{C}$, interface voltage $4.5 \mathrm{kV}$ and collision gas $230 \mathrm{kPa}$. Indapamide and zolpidem tartarate (internal standard, IS) were quantitated in multiple reaction monitoring (MRM) using the transition of $\mathrm{m} / \mathrm{z} 366.1 \rightarrow 132.15$ and $309.0 \rightarrow$
236.10 respectively. The collision energy applied was $20 \mathrm{~V}$ for indapamide and $35 \mathrm{~V}$ for the IS.

\section{Preparation of calibration standards (CS) and quality control (QC) samples}

Indapamide and zolpidem tartarate were dissolved in methanol to yield a stock solution of $1 \mathrm{mg} / \mathrm{mL}$ each. Indapamide working solutions, in concentrations ranging from 0.50 to $50 \mathrm{ng} / \mathrm{mL}$, were prepared by serial dilution of the stock solution. The calibration standards (CS) and quality control (QC) samples were prepared by spiking $50 \mu \mathrm{L}$ of each working standard solution with $150 \mu \mathrm{L}$ blank human serum. IS working solution of $600 \mathrm{ng} / \mathrm{mL}$ was prepared by dilution of IS stock solution in methanol.

\section{Sample preparation by automated solid-phase extraction (SPE) procedure}

A volume of $200 \mu \mathrm{L}$ of a CS or QC samples was placed in a testing tube and $20 \mu \mathrm{l}$ IS working solution and $400 \mu \mathrm{L}$ of $100 \mathrm{mM} \mathrm{K} \mathrm{HPO}_{4}(\mathrm{pH} 10.5)$ were added and homogenized by vortex-mixed. Phenomenex Strata-X-Drug N Polymer RP $(60 \mathrm{mg} / 3 \mathrm{~mL})$ cartridges were used for analyte extraction. The automated SPE was carried out on RapidTrace workstation according to following steps: a) loading $0.5 \mathrm{~mL}$ sample; b) washing with $2 \mathrm{~mL}$ mixture of methanol and water in ratio 10:90 (v/v); c) drying for $3 \mathrm{~min}$ with $\mathrm{N}_{2}$ gas; d) elution with $1 \mathrm{~mL}$ methanol. The eluate was transferred to vials and $10 \mu \mathrm{l}$ was injected into the LC-MS/ MS system.

\section{Bioanalytical method validation}

A validation according to the EMA guideline was performed for the determination of indapamide in human serum (EMA 2011).

For selectivity assessment, blank samples from six different subjects were tested using the proposed method. The obtained results were compared with the lower limit QC samples $(0.50 \mathrm{ng} / \mathrm{mL})$.

The effect of serum constituents over the ionization efficinecy of indapamide and IS was determined by comparing the responses of the post-extracted blank serum (obtained from 6 different donors) spiked with analyte and IS with response of analyte from neat standard samples (analyte and IS spiked with methanol instead of blank serum). The matrix factor (MF) for indapamide was determined at low QC and high QC, whereas the MF for IS was determinate at single concentration of $20 \mathrm{ng} / \mathrm{mL}$. The IS normalized MF was obtained by dividing the indapamide MF by the MF of IS.

A calibration curve was constructed from blank sample (serum sample without analyte and IS), a zero sample (serum with IS) and seven non-zero samples covering the range from $0.50-50 \mathrm{ng} / \mathrm{mL}$. The calibration curves ob- 
tained from six days were fitted to the ordinary linear regression through the measurement of the peak area ratio of the analyte to IS. The accuracy and precision of the method were evaluated by within-run $(n=5)$ and between-run $(n=30)$ assay using QC samples at concentrations of 0.50 $\mathrm{ng} / \mathrm{mL}$ (lower limit QC); $1 \mathrm{ng} / \mathrm{mL}$ (low QC), $25 \mathrm{ng} / \mathrm{mL}$ (medium QC) and $40 \mathrm{ng} / \mathrm{mL}$ (high QC). For within-run accuracy and precision, five samples per concentration were prepared and analyzed in the same day. For between-run accuracy and precision, five determinations per concentration per run from three runs were analyzed on two different days.

Stability of indapamide in human serum was evaluated by analyzing replicates $(n=3)$ that were exposed to different conditions ( $24 \mathrm{~h}$ at room temperature, $12 \mathrm{~h}$ in autosampler, three freeze-thaw cycles and 1 month stored at $-20{ }^{\circ} \mathrm{C}$ ) at two concentrations ( $1 \mathrm{ng} / \mathrm{mL}$ and $40 \mathrm{ng} / \mathrm{mL})$. The QC samples are analyzed against calibration curve and compared to the nominal concentrations. The stability of stock solutions of the analytes which were stored at room temperature for $24 \mathrm{~h}$ and one month at $2-8{ }^{\circ} \mathrm{C}$ was also tested.

\section{Results and discussion}

\section{Method development}

The strategy for obtaining high-throughput bioanalytical method is composed of fast chromatographic separation on one hand and automated; fast and simple sample cleanup procedure on the other hand. The fast chromatograph- ic separation is the first segment, which plays an important role in obtaining high sample throughput. The existing literature data have shown that the use of fully-porous particles (Chen et al., 2006; Ding et al., 2006 and Morihisa et al., 2008) or monolithic columns (Albu et al., 2005) did not provide separation of indapamide within short runtime. In our previous work, method for determination of indapamide in human whole blood using core-shell stationary phase was developed (Nakov et al., 2013). These particles are not fully porous; analytes spend less time diffusing into and out of the pores, resulting in faster mass transfer and shorter run time. It was observed that under the optimized chromatographic conditions indapamide and IS eluted in less than 3 minutes. Prompted by these results, the reported chromatographic conditions were applied in the new method for determination of indapamide in human serum. The retention time of indapamide and IS extracted from human serum was $1.55 \mathrm{~min}$ and $1.66 \mathrm{~min}$, respectively (Fig.1), in contrast to 11 min reported by Albu et al. (2005) and 16 min reported by Morihisa et al. (2008). The benefit from short analysis time is not only in the increased sample throughput, but also in dramatically decreased solvent consumption.

One of the important factors in a quality quantitative method is the availability of a quality IS that plays an important role in normalizing (and therefore reducing) variability (Mulvana 2010). Zolpidem tartarate was chosen as internal standard because it not only posses similar physicochemical properties as the analyte, but it also coelute with the analyte and, thus, will experience the same ionization suppression/enhancement as the analyte.
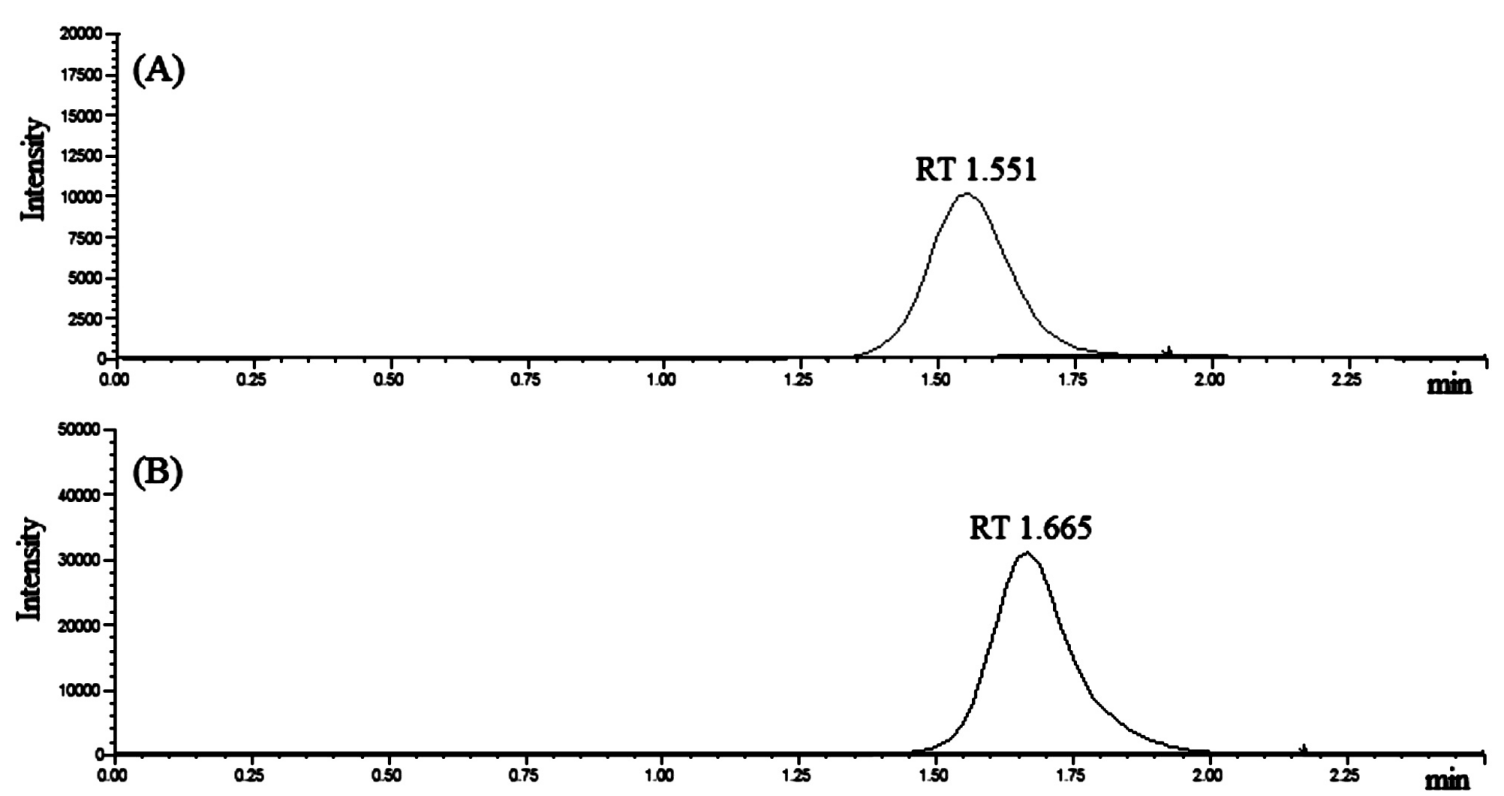

Fig. 1 MRM chromatograms for indapamide (A) and internal standard (B) from medium CS. Conditions: Kinetex C18 column, mobile phase consisting of acetonitrile: $2 \mathrm{mM}$ ammonium acetate $(90: 10 \mathrm{v} / \mathrm{v})$, containing $0.5 \mathrm{~mL}$ formic acid in $1 \mathrm{~L}$ buffer; flow rate of $0.2 \mathrm{~mL} / \mathrm{min}$ 


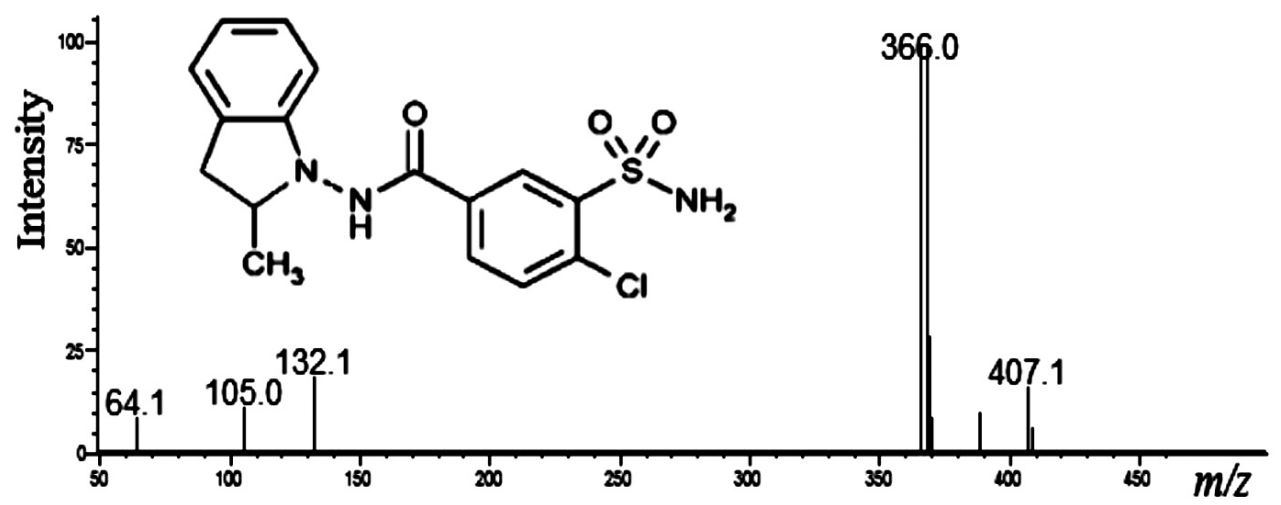

Fig. 2 Chemical structure and $\mathrm{Q}_{3}(+)$ mass scan spectrum of indapamide.

The indapamide molecule contains $\mathrm{NH}_{2}$ group, which could be ionized efficiently using ESI+ mode. The chemical structure and the $\mathrm{Q}_{3}(+)$ mass scan spectrum of indapamide are presented in Figure 2. The molecular weight of indapamide is $365 \mathrm{~g} / \mathrm{mol}$, so $\mathrm{m} / \mathrm{z} 366.0$ correspond to protonated molecular ion $[\mathrm{M}+\mathrm{H}]^{+}$of indapamide and ion with $m / z 132.1$ correspond to the major fragment. The ion mass of $m / z 407.1$ probably comes from the adduct ion of indapamide with acetonitrile; $m / z 64.1$ derives from ammonium formate cluster $\left[\mathrm{CHOONH}_{4}+\mathrm{H}\right]^{+}$and the possible origin of the ion with $\mathrm{m} / \mathrm{z} 105.0$ is from acetonitrile/ ammonium formate cluster.

The second part from obtaining high-throughput bioanalytical method, as stated above, is having an automated, fast and simple sample clean-up procedure. For that purpose our research was towards developing SPE which as a technique has number of advantages over LLE. The SPE procedure was performed on polymeric mixed-mode sorbent which can retain analytes by several different sorbentanalyte interactions. Indapamide is weak basic compound (pKa 8.3, Dollery, C. 1999), so its retention on the sorbent can be achieved as ionic or as neutral form. In that direction experiments were made using buffer at $\mathrm{pH}$ two units below and two units above its $\mathrm{pKa}$ value. The best results were obtained using buffer $\left(100 \mathrm{mM} \mathrm{KH}_{2} \mathrm{PO}_{4}\right)$ at $\mathrm{pH}$ 10.5. In comparison, the extraction of indapamide from blood using buffer at $\mathrm{pH} 6.8$, which is close to physiolog- ical $\mathrm{pH}$, was performed. Optimization of the washing step of the SPE is crucial, in one hand to remove matrix components which otherwise may impose ionization suppression/enhancement of the analytes and to obtain satisfactory recovery on the other hand. The use of methanol and water in ratio 20:80 $(v / v, \%)$ as a washing solvent resulted in low recovery (around 60\%). To avoid washing of the analyte from the cartridge, methanol and water in ratio 10:90 $(v / v)$ was used, but this led to unsatisfactory removal of the matrix components. The matrix effect observed under these conditions, in term of suppression of ionization was around $25 \%$. This problem was solved when larger volume of washing solvent was used $(2 \mathrm{~mL}$ instead of $1 \mathrm{~mL})$. In comparison, removal of matrix effect from whole blood, due to its complexity, was accomplished using $4 \mathrm{~mL}$ washing solvent.

The extraction yield under the optimized conditions is presented in Table 1. Recovery was calculated by comparing mean peak areas obtained from extraction of QC samples and extracted blank serum spiked with the corresponding concentrations of indapamide and IS. The optimized SPE procedures for extraction of indapamide from serum and blood gave similar recovery values. The mean recovery for indapamide from serum was around $90 \%$ and from blood was around $92 \%$. The mean recovery for IS was around $80 \%$ in either case.

Table 1. Absolute recovery of indapamide and internal standard from spiked serum samples

\begin{tabular}{lllc}
\hline \hline Compound & Concentration $(\mathrm{ng} / \mathrm{mL})$ & Recovery $(\%)$ & Variability $(\mathrm{CV}, \%)$ \\
\hline \multirow{2}{*}{ Indapamide } & $1 \mathrm{ng} / \mathrm{mL}$ (low QC) & $89.25(\mathrm{n}=3)$ & 2.45 \\
& $25 \mathrm{ng} / \mathrm{mL}$ (medium QC) & $90.36(\mathrm{n}=3)$ & 1.87 \\
& $40 \mathrm{ng} / \mathrm{mL}$ (high QC) & $89.75(\mathrm{n}=3)$ & 1.13 \\
Internal standard & $20 \mathrm{ng} / \mathrm{mL}$ & $79.10(\mathrm{n}=9)$ & 1.56 \\
\hline
\end{tabular}



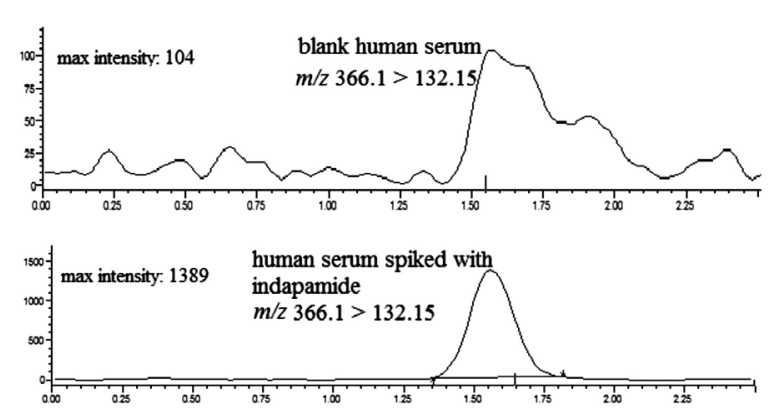

(a)

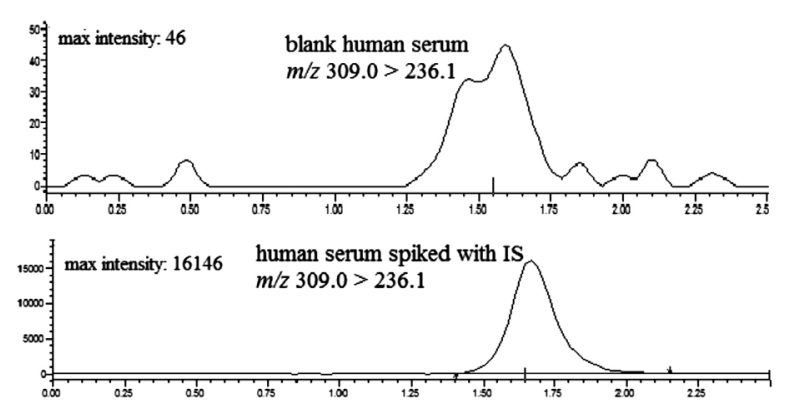

(b)

Fig. 3 MRM chromatogram for: a) indapamide $\mathrm{m} / \mathrm{z}$ 366.1>132.15 in blank human serum (top); blank serum spiked with indapamide $(0.50 \mathrm{ng} / \mathrm{mL}$, bottom); b) internal standard $\mathrm{m} / \mathrm{z} 309>236.10$ in blank human serum (top); blank serum spiked with IS (20 ng/mL, bottom)

\section{Method validation}

The selectivity met the acceptance criteria that the mean response obtained from the blank samples was less than $20 \%$ of the lower limit quantification for indapamide and less than 5\% for IS. Representative chromatograms of lower limit QC and blank human serum are presented in Figure 3.

Matrix effects are the alteration (suppression or enhancement) of the ionization efficiency by the presence of coeluting substances. These effects are not seen in the chromatogram but have deleterious impact on the method accuracy, precision and sensitivity (Taylor 2005). In this study, the matrix effect was assessed through determination of the IS normalized MF (EMA 2011). For that purpose six different sources of matrices were used. It was found that the coefficient of variation (CV \%) of the IS normalized $\mathrm{MF}$ at two concentration levels were within the acceptance criteria of 15\% (2.87\% for LQC and 3.15\% for high QC). The matrix effect assessment has demonstrated that the inter-subject variability does not affect the reproducibility of the assay.

The indapamide MF obtained from serum was around $97 \%$, which means that the ionization suppresion was almost 3\%. For comparison, the indapamide MF obtained from blood indicates that the matrix effect is almost $8 \%$, resulting in higher suppression of the ionization efficiency (Table 2).

Table 2. Comparison of indapamide MF (\%) obtained from serum and from blood

\begin{tabular}{lcc}
\hline \hline & \multicolumn{2}{c}{ Indapamide MF (\%) } \\
& Low QC & High QC \\
\hline Serum $(\mathrm{n}=6)$ & 96.45 & 97.84 \\
Blood $(\mathrm{n}=6)$ & 91.60 & 92.26 \\
\hline
\end{tabular}

The calibration curve for indapamide was establish in the range from $0.50-50 \mathrm{ng} / \mathrm{mL}$ using seven-point calibration curve from six different days. The regression equation was $\mathrm{y}=0.321389 \mathrm{x}+0.00106751$ with a coefficient of determination 0.9997 . The $\%$ accuracy observed for the back-calculated concentrations for the calibration curves was within 94.80-107.91; while the \% precision values ranged from 0.31-6.60.

The results for accuracy and precision are presented in Table 3. The accuracy was expressed as the $\%$ deviation for the lower limit QC, low QC, medium QC and high QC. The within-run accuracy ranged between $-3.46 \%$ and $9.15 \%$; while between-run ranged from $-4.73 \%$ and $10.12 \%$. The precision was expressed as $\mathrm{CV} \%$. The within-run precision ranged between $2.45 \%$ and $4.23 \%$. The between-run precision was between $2.87 \%$ and $5.14 \%$. The method met the recommended acceptance criteria $(\%$ Deviation and $\% \mathrm{CV}$ $\pm 20 \%$ for lower limit QC and $\pm 15 \%$ for low QC, medium QC and high QC).

Table 3. Accuracy and precision of indapamide in human serum

\begin{tabular}{lccccc}
\hline \hline $\begin{array}{c}\text { Quality control } \\
\text { samples }\end{array}$ & $\begin{array}{c}\text { Nominal conc. } \\
(\mathrm{ng} / \mathrm{mL})\end{array}$ & Deviation (\%) & $\begin{array}{c}\text { Within-run assay (n=5) } \\
\text { Precision } \\
(\mathrm{CV} \%)\end{array}$ & $\begin{array}{c}\text { Between-run assays (n=30) } \\
\text { Deviation (\%) }\end{array}$ & $\begin{array}{c}\text { Precision } \\
(\mathrm{CV} \%)\end{array}$ \\
\hline Low limit QC & 0.50 & 9.15 & 4.23 & 10.12 & 5.14 \\
Low QC & 1 & -3.46 & 4.04 & -4.73 & 4.40 \\
Medium QC & 25 & 1.22 & 2.45 & 1.65 & 2.87 \\
High QC & 40 & -1.24 & 2.62 & -2.74 & 3.03 \\
\hline
\end{tabular}


Table 4. Stability of indapamide in human serum $(n=3)$

\begin{tabular}{|c|c|c|c|c|}
\hline \multirow{2}{*}{ Nominal concentration } & \multicolumn{2}{|c|}{$1.0 \mathrm{ng} / \mathrm{mL}$} & \multicolumn{2}{|l|}{$40 \mathrm{ng} / \mathrm{mL}$} \\
\hline & Recovery (mean) $(\%)$ & $\mathrm{CV}(\%)$ & Recovery (mean) (\%) & $\mathrm{CV}(\%)$ \\
\hline $24 \mathrm{~h}$ room temperature & 98.89 & 2.15 & 101.25 & 2.37 \\
\hline Autosampler stability (after 12h) & 99.23 & 1.78 & 100.57 & 1.95 \\
\hline Three freeze-thaw cycles & 95.43 & 3.45 & 97.25 & 5.14 \\
\hline Long term stability $\left(-20^{\circ} \mathrm{C}\right)$ & 92.14 & 4.27 & 95.27 & 6.62 \\
\hline
\end{tabular}

The stability of indapamide in human serum under various conditions is presented in Table 4 . The results were found to be within the acceptable limits ( $\pm 15 \%$ of the nominal concentration). The stability data of indapamide indicated that the analyte is stable in serum at room temperature for $24 \mathrm{~h}$, after $12 \mathrm{~h}$ in autosampler, three freeze-thaw cycles and after 3 month stored at $-20^{\circ} \mathrm{C}$. The stock solutions of indapamide and IS were stable at room temperature for $24 \mathrm{~h}$ and at $2-8^{\circ} \mathrm{C}$ for one month.

\section{Conclusions}

In this research we have developed an automated SPE procedure which in combination with fast chromatographic separation resulted in obtaining high-throughput LCMS/MS method for determination of indapamide in human serum. The benefit from automated SPE procedure is in its simplicity, good recovery and low variability values. The results of all validation parameters have shown that the present method will generate reliable bioanalytical data during the real study sample analysis. All the abovementioned makes the proposed method suitable for analyzing large number of samples involved in pharmacokinetic studies.

\section{References}

Albu, F., Georgita, C., David, F., Medvedovic, A., 2005. Liquidchromatography-electrospray tandem mass spectrometry method for determination of indapamide in serum for single/ multiple dose bioequivalence studies of sustained release formulations. J Chromatogr B Analyt Technol Biomed Sci 816 (1-2), 35-40.

Chen, W.D., Liang, Y., Zhang, H.,Li, H., Xiong, Y., Wang, G.J., Xie, L., 2006. Simple, sensitive and rapid LC-MS method for the quantification of indapamide in human plasmaapplication to pharmacokinetic studies. J Chromatogr B 842, 58-63.

Choi, R.L., Rosenberg, M., Grebow, P.E., Huntley, T.E., 1982. High performance liquid chromatographic analysis of indapamide (RHC 2555) in urine, plasma and blood. J Chromatogr 230 (1), 181-187.

Ding, L., Yang, L., Liu, F., Ju, W., Xiong, N., 2006. A sensitive LC-ESI-MS method for the determination of indapamide in human plasma: method and clinical applications. J Pharm Biomed Anal 42 (2), 213-217.
Dollery, C., 1999. Therapeutic drugs, second edition. Churchill Livingstone, Edinburgh, United Kingdom

Eeckhaut, A.V., Lanckmans, K., Sarre, S., Smolders, I., Michotte, Y., 2009. Validation of bioanalytical LC-MS/MS assays: Evaluation of matrix effects. J Chromatogr B 877, 21982207.

European Medicines Agency. Guideline on validation of bioanalytical methods. Committee for Medical Products for Human Use (CHMP).2011. http://www.ema.europa.eu/docs/ en GB/document library/Scientific guideline/2011/08/ WC 500109686.pdf

Gaetani, E., Laureri, C.F., Vitto, M., Elie, G.F., Novarini, A., 1986. Determination of indapamide in plasma by HPLC. Boll Chim Farm 125 (1), 35-37.

Hang, T.J., Zhao, W., Liu, J., Song, M., Xie, Y., Zhang, Z., Shen, J., Zhang, Y., 2006. A selective HPLC method for the determination of indapamide in human whole blood: application to a bioequivalence study in Chinese volunteers. J Pharm Biomed Anal 40 (1), 202-205.

Miller, R.B., Dadgar, D., Lalande, M., 1993. High performance liquid chromatographic method for the determination of indapamide in human whole blood. J Chromatogr 614 (2), 293-298.

Morihisa, H., Fukata, F., Muro, H., Nishimura, K.I., Makino, T., 2008. Determination of indapamide in human serum using 96-well solid-phase extraction and high-performance liquid chromatography-tandem mass spectrometry (LC-MS/MS). J Chromatogr B 870, 126-130.

Mulvana, D., 2010. Critical topics in ensuring data quality in bioanalytical LC-MS method development. Bioanal 2 (6), 1051-1072.

Nakov, N., Mladenovska, K., Labacevski, N., Dimovski, A., Petkovska, R., Dimitrovska, A., Kavrakovski, Z., 2013. Development and validation of automated SPE-LC-MS/MS method for determination of indapamide in human whole blood and its application on real study samples. Biomed Chromatogr 27, 1540-1546.

Taylor. P.J., 2005. Review Matrix effects: The Achilles heel of quantificatative high-performance liquid chromatographyelectrospray-tandem mass spectrometry. Clin Biochem 38, 328-334.

Zendelovska D, Stafilov T, Stefova M. 2003. Optimization of solid-phase extraction method for determination of indapamide in biological fluids using high performance liquid chromatography. J Chromatogr B 788 (1), 199-206.

Zhou, S., Song, Q., Tang, Y., Naidong. W., 2005. Critical review of development, validation, and transfer for high throughput bioanalytical LC-MS/MS methods. Curr Pharmaceut Anal, $1(1), 3-14$. 


\title{
Резиме
}

\section{Високо-продуктивен LC-MS/MS метод за определување на индапамид во серум}

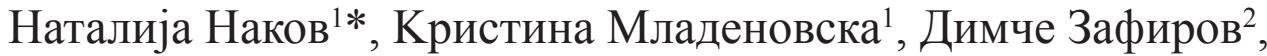 \\ Александар Димовски ${ }^{1}$, Руменка Петковска ${ }^{1}$, Анета Димитровска ${ }^{1}$ \\ и Зоран Кавраковски ${ }^{1}$

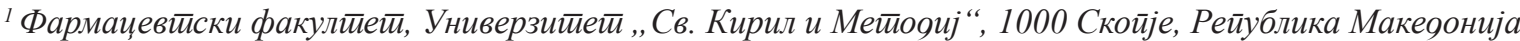

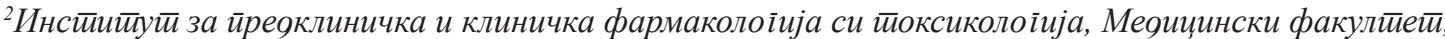 \\ Универзииееӣ „Св. Кирил и Мейояиј“, 1000 Скойје, Рейублика Макеоонија
}

Клучни зборови: индапамид, серум, цврсто-фазна екстракција, течна хроматографија спрегната со тандем масена спектрометрија

Едноставната, автоматизирана постапка на цврсто-фазна екстракција (solid-phase extraction, SPE) комбинирана со течна хроматографија спрегната со тандем масена спектрометрија (liquid chromatography-tandem mass spectrometry, LC-MS/MS) резултираше со добивање на високо-продуктивен метод за определување на индапамид во серум. За SPE користен е полимерен сорбент, додека пак за квантитативното определување на аналитите користена е електроспреј јонизација во позитивен мод. Добиените вредности за приносот на екстрактивната постапка се движат од 89,25-90,36\% за индапамид и 79, $10 \%$ за внатрешениот стандард. Експериментално беше потврдено дека матрикс ефектот има незначително влијание врз ефикасноста на јонизацијата. Валидацијата на методот покажа дека предложениот метод обезбедува точни, прецизни и репродуцибилни резултати во опсег од 0,50-50 ng/mL. Дополнително, направена е споредба на овој методот со методот за определување на индапамид во крв (развиен во наше претходно истражување) по однос на постапката за екстракција и матрикс ефектот. 
